\title{
Long Intergenic Non-Protein Coding RNA 1565
}

National Cancer Institute

\section{Source}

National Cancer Institute. Long Intergenic Non-Protein Coding RNA 1565. NCI

Thesaurus. Code C136973.

Long intergenic non-protein coding RNA 1565 ( $\sim 3 \mathrm{~kb})$ is encoded by the human

LINC01565 gene. This non-coding RNA may be involved the suppression of cell growth. 